\title{
Law and History Review
}

Articles by

G. Blaine Baker

Michael Les Benedict

Elaine Clark

Charles McClain

Robert C. Palmer

Richard Polenberg

Reply by

L. R. Poos \& R. M. Smith

Book Reviews 


\section{Law and History Review}

Volume 3

\author{
Lloyd Bonfield \\ Tulane University \\ School of Law \\ Associate Editor \\ Clive Holmes \\ Cornell University
}

Fall 1985

Number 2
Editors

\author{
Russell Osgood \\ Cornell Law School
}

\author{
Book Review Editor \\ Adam Hirsch \\ Florida State University \\ College of Law
}

\section{Editorial Board}

Barbara Aronstein Black
Columbia University
School of Law
C. W. Brooks
University of
Durham
Paul Finkelman
State University of
New York at
Binghamton
Robert W. Gordon
Stanford Law School

\section{Douglas Hay \\ Osgoode Hall Law School, York University}

R. H. Helmholz University of Chicago Law School
Michael Hoeflich University of Illinois College of Law

William E. Nelson New York University School of Law

\section{Larry Poos \\ The Catholic \\ University of America}

Stephen Presser

Northwestern University

School of Law

Marylynn Salmon University of Maryland Baltimore County

Richard Smith All Souls College Oxford

Keith Wrightson Jesus College Cambridge

\section{Kathleen E. Rourke, Editorial Assistant}

Law and History Review is a semi-annual publication of Cornell Law School and the American Society for Legal History. The purpose of the Review is to further research and writing in the fields of the social history of law and the history of legal ideas and institutions. Publication of the Review is made possible in part by financial assistance provided by the Law-Milton and Eleanor Gould Fund.

The Editors welcome unsolicited manuscripts, books for review and suggestions concerning the Review. Manuscripts should be submitted in duplicate; send one copy to the editorial office at Cornell and a second copy to Professor Lloyd Bonfield at Tulane University School of Law, New Orleans, LA 70118. The text should be typed, double-spaced, on $81 / 2^{\prime \prime} \times 11^{\prime \prime}$ paper with ample margins on all sides. Footnotes should be typed, double-spaced, separate from the text. Footnotes should conform to the Law and History Review style sheet, a copy of which is available on request.

Editorial and business communications should be directed to Editor, Law and History Review, Cornell Law School, Myron Taylor Hall, Ithaca, NY 14853-4901 (telephone: 607/256-7477). ISSN 0738-2480

Subscription information can be found on the rear cover.

(C) 1985 Cornell University. 


\section{Table of Contents}

\section{Articles}

The Reconstitution of Upper Canadian

Legal Thought in the Late-Victorian Empire . . . . . . . . . . . . 219 by $\mathrm{G}$. Blaine Baker

Laisser-Faire and Liberty: A Re-Evaluation of the

Meaning and Origins of Laisser-Faire

Constitutionalism.

by Michael Les Benedict

The Custody of Children in English

Manor Courts

by Elaine Clark

The Chinese Struggle for Civil Rights in

19th Century America: The Unusual Case

of Baldwin v. Franks.

by Charles McClain

The Economic and Cultural Impact of

the Origins of Property: 1180-1220

by Robert C. Palmer

Progressivism and Anarchism: Judge

Henry D. Clayton and the Abrams Trial

by Richard Polenberg

\section{Reply}

'Shades Still on the Window':

A Reply to Zvi Razi

by L. R. Poos and R. M. Smith

\section{Book Reviews}

The Justices of the Peace, 1679-1760-

Norma Landau

reviewed by James W. Ely, Jr.

Community Class and Careerism, Cheshire and

Lancashire Society in the Age of Sir Gawain and

the Green Knight-Michael J. Bennett

reviewed by Barbara J. Harris

Law in Colonial Massachusetts, 1630-1800

(Volume 62, Publications of the Colonial Society of

Massachusetts)—Daniel R. Coquillette, ed. . reviewed by David Thomas Konig

Constitutional Faiths: Felix Frankfurter,

Hugo Black, and the Process of Judicial

Decision Making-Mark Silverstein .

reviewed by Sanford Levinson 
The Roots of American Bureaucracy-

William E. Nelson ............................. 440

reviewed by Arnold Milton Paul

Supreme Court Justice Joseph Story-

R. Kent Newmyer ................................ 444

reviewed by M. J. Solomon

A Comprehensive Bibliography of American

Constitutional and Legal History, 1896-1979-

Kermit L. Hall ................................... 447

reviewed by Erwin C. Surrency

The Iconoclast as Reformer: Jerome

Frank's Impact on American Law-

Robert Jerome Glennon .............................. 449 reviewed by Mark Tushnet

Ambivalent Legacy: A Legal History of

the South - David J. Bodenhamer and

James W. Ely, Jr., eds........................ 451

reviewed by John $\mathbf{R}$. Wunder 